\title{
14. The Use of Cloned DNA Probes for Diagnosis of Noncultivable Plant Mollicutes
}

\author{
By Sujun Deng and Chuji Hiruki \\ Department of Plant Science, University of Alberta Edmonton, \\ Alberta, Canada T6G 2P5 \\ (Communicated by Naohide Hiratsuka, M. J. A., March 12, 1990)
}

Introduction. Clover proliferation, first found in Alberta in 1964 and then known as a yellows type virus disease of alsike clover (Trifolium hybridum L.), is a disease associated with noncultivable mollicutes (hereafter referred to as mycoplasmalike organisms, MLOs) (Chen and Hiruki, 1975) and believed to be distinct from clover phyllody and aster yellows (Chiykowski, 1965). Although MLOs are associated with important diseases of a variety of crops and trees worldwide (Hiruki, 1988), little is known about their classification due to the lack of effective techniques to compare these pathogens. The major obstacle is the inability to isolate them in vitro and culture these microorganisms on artificial media. While some progress has been made in detecting plant pathogenic MLOs by means of polyclonal (da Rocha et al., 1986; Sinha and Chiykowski, 1984, 1986) and monoclonal (Lin and Chen, 1985, 1986) antibodies, the use of cloned chromosomal or extrachromosomal MLO IDNA from infected plants and insects as probes is a promising approach to rapid and accurate diagnosis of MLO-associated diseases (Davis et al., 1988; Kirkpatrick et al., 1987; Lee and Davis, 1988).

Materials and methods. Plants and MLO isolates. Four MLO isolates; eastern aster yellows (EAY, a New York isolate), clover proliferation (CP) (Chen and Hiruki, 1975), potato witches'-broom (PWB) (Chen and Hiruki, 1978), and western aster yellows (AY27, a subculture of AP-1, Alberta isolate) were maintained in periwinkle (Catharanthus roseus) as described previously (da Rocha et al., 1986).

CP MLO-enriched fraction and isolation of DNA for molecular cloning. A CP MLO-enriched fraction was prepared by macerating enzyme-treated midribs and petioles of CP MLO-infected periwinkle plants (Lee and Davis, 1983). Nucleic acids were isolated and purified from the CP MLO-enriched extract as described previously (Lee and Davis, 1988). The resulting preparation containing CP MLO DNA or host plant DNA was dissolved in $10 \mathrm{mM}$ Tris-HCl, pH 8.0, $1 \mathrm{mM}$ EDTA $(1 \mu \mathrm{g} / \mu \mathrm{l})$.

Crude nucleic acids for DNA hybridization. One gram of midribs and petioles was pulverized in liquid nitrogen in a mortar and pestle. After adding $10 \mathrm{ml}$ of $100 \mathrm{mM}$ Tris- $\mathrm{HCl} \mathrm{pH} 8.0,50 \mathrm{mM}$ EDTA pH 8.0, $500 \mathrm{mM} \mathrm{NaCl}, 10 \mathrm{mM}$ 2-mercaptoethanol, the homogenate was dispersed. This homogenate was incubated with $2 \mathrm{ml}$ of $10 \%$ sodium dodecyl sulfate (SDS) at $65^{\circ} \mathrm{C}$ for $15 \mathrm{~min}$, then $4 \mathrm{ml}$ of $5 \mathrm{M}$ potassium acetate was added before incubation at $0^{\circ} \mathrm{C}$ for $30 \mathrm{~min}$. After centrifugation at $12,000 \mathrm{~g}$ for $30 \mathrm{~min}$, the supernatant was extracted twice with $8 \mathrm{ml}$ of TE-saturated phenol and $8 \mathrm{ml}$ of chloroform-isoamyl alcohol $(24: 1$, $\mathrm{v} / \mathrm{v})$. The aqueous phase was extracted once with $16 \mathrm{ml}$ of chloroform-isoamyl alcohol. The nucleic acids were precipitated with ethanol and then dissolved in TE buffer. 


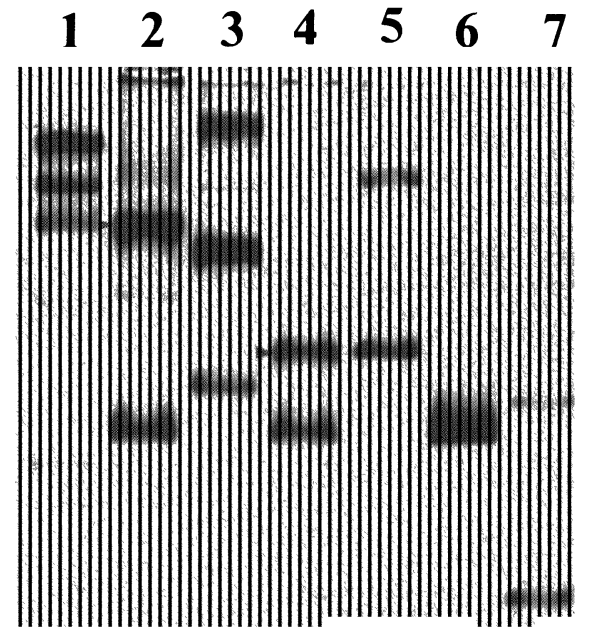

Fig. 1. Restriction endonuclease analysis of cloning vector and CP MLO-specific recombinant plasmids pCP16 and pCP110 in 1\% agarose gel electrophoresis. Lane 1, lambda DNA digested with HindIII, from top to bottom $(\mathrm{kb}): 23.1,9.4$, 6.6, 4.4, 2.3, 2.0; Lane 2, pCP110 digested with EcoRI and HindIII. The upper band (arrow) is a CP MLO insert of molecular weight $5.96 \mathrm{~kb}$.; Lane 3, undigested pCP110, plasmid pUC19 with CP MLO DNA insert; Lane 4, pCP16 digested with EcoRI and HindIII. The upper band is a CP MLO DNA insert with a molecular weight of $2.99 \mathrm{~kb}$; Lane 5 , undigested pCP16, plasmid pUC19 with CP MLO DNA insert. Lane 6, plasmid pUC19 digested with EcoRI and HindIII; Lane 7, undigested plasmid pUC19.

DNA cloning and recombinant screening. A preparation containing CP MLO DNA and plant DNA $(10 \mu \mathrm{g}$ in $50 \mu \mathrm{l})$ was digested with both EcoRI and HindIII restriction endonucleases (BRL, Bethesda, MD) at $37^{\circ} \mathrm{C}$ for $1 \mathrm{hr}$ and for another 30 min with the same amount of HindIII. The reaction was stopped at $65^{\circ} \mathrm{C}$ for $10 \mathrm{~min}$. The solution was extracted twice with a half volume of TE-saturated phenol and a half volume of chloroform-isoamyl alcohol. The DNA fragments were precipitated by ethanol and then dissolved in TE to a concentration of 40-50 ng/ $\mu$ l. Plasmid pUC19 (BRL, Bethesda, MD) was completely digested with EcoRI and HindIII. The linear plasmid was purified and dissolved in TE to a concentration of $10 \mathrm{ng} / \mu \mathrm{l}$. One microliter of both DNA fragments and plasmid DNA was incubated with $1 \mu \mathrm{l} 5 \times$ ligase buffer and T4 DNA ligase at $14^{\circ} \mathrm{C}$ for $15 \mathrm{hr}$ and the ligation mixture was diluted tenfold. The diluted mixture was used to transform competent $E$. coli DH5a cells (BRL, Bethesda, MO). The CP MLOspecific colonies were screened by dot-blot hybridization with ${ }^{32} \mathrm{P}$-labelled nucleic acids from CP MLO-infected periwinkle as well as healthy periwinkle plants. Minipreps of recombinant plasmid DNA were prepared from ampicillin-resistant white colonies (Ausubel et al., 1987). Plasmid DNA was denatured at $95^{\circ} \mathrm{C}$ for $10 \mathrm{~min}$ followed by chilling on ice. About $5 \mu \mathrm{l}$ plasmid DNA (50 ng) was spotted on GeneScreenPlus (NEN/Dupont, Boston, MA). Nucleic acids $(0.5 \mu \mathrm{g})$ from periwinkle plants were labelled with $50 \mu \mathrm{Ci}\left[\alpha^{-32} \mathrm{P}\right] \mathrm{dCTP}(3000 \mathrm{Ci} / \mathrm{mmol}, \mathrm{NEN} /$ Dupont, Boston, MA) using a nick-translation kit (BRL, Bethesda, MA). Prehybridization and hybridization of plasmid DNA immobilized on GeneScreenPlus with nick-translated DNA probes $\left(0.5-1 \times 10^{6} \mathrm{cpm} / \mathrm{ml}\right)$ were done according to the 


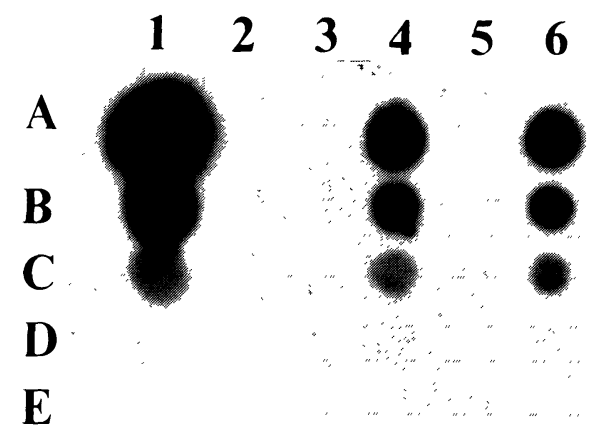

Fig. 2. Specificity and relative sensitivity of a DNA probe using pCP16 for the detection of MLO DNA in crude nucleic acids. Twofold serial dilutions of the crude nucleic acids extracted from midribs and petioles of periwinkle plants were blotted on GeneScreenPlus membrane. The membrane was probed with ${ }^{32} \mathrm{P}$-labelled pCP16. Samples in rows A-E: A, $120 \mu \mathrm{g} ; \mathrm{B}, 60 \mu \mathrm{g} ; \mathrm{C}, 30 \mu \mathrm{g} ; \mathrm{D}, 15 \mu \mathrm{g} ; \mathrm{E}, 7.5 \mu \mathrm{g}$. Columns 1-6: 1, plasmid pUC19 plus DNA insert; 2, crude nucleic acids from healthy; 3, EAY MLO-, 4, PWB MLO-; 5, AY27 MLO-, and 6, CP MLO-infected plants, respectively. The same hybridization sensitivity was obtained when pCP110 was used for probing (data not shown).

manufacturer's instruction manual (NEN/Dupont, Boston, MA). When plasmid DNA hybridized with labelled DNA from CP MLO-infected periwinkle plants but not with labelled DNA from healthy periwinkle plants, it was considered that the colonies contained CP MLO-specific DNA sequences. These colonies were further confirmed by Southern-blot hybridization (Southern, 1975). The size of the specific MLO DNA insert was estimated by restriction endonuclease digestion and agarose gel electrophoresis.

Dot-blot hybridization. Crude nucleic acids were denatured at $95^{\circ} \mathrm{C}$ for 10 min followed by chilling on ice. The nucleic acid samples, in twofold serial dilutions in TE, were loaded onto GeneScreenPlus membrane using a dot-blot apparatus (Tyler Research Corporation, Edmonton). The DNA was fixed by baking the membrane at $80^{\circ} \mathrm{C}$ for $2 \mathrm{hr}$. The membrane was prehybridized at $42^{\circ} \mathrm{C}$ for $2 \mathrm{hr}$ in a solution containing $50 \%$ formamide, $0.9 \mathrm{M} \mathrm{NaCl}, 0.06 \mathrm{M}$ $\mathrm{NaH}_{2} \mathrm{PO}_{4} \cdot \mathrm{H}_{2} \mathrm{O}, 0.006 \mathrm{M} \mathrm{Na} 2 \mathrm{EDTA} \cdot \mathrm{H}_{2} \mathrm{O}, 0.1 \%$ Ficoll, $0.1 \%$ polyvinylpyrrolidone, $0.1 \%$ bovine serum albumin, $1 \% \mathrm{SDS}, 200 \mu \mathrm{g} / \mathrm{ml}$ sheared, denatured salmon sperm DNA (Maniatis et al., 1982). The prehybridization solution was replaced with a similar solution containing $5 \%$ dextran sulfate and denatured ${ }^{32} \mathrm{P}$-labelled recombinant plasmid DNA $\left(0.5 \times 10^{6} \mathrm{cpm} / \mathrm{ml}\right)$. The membrane was incubated at $42^{\circ} \mathrm{C}$ for at least $15 \mathrm{hr}$, washed under high stringency conditions, and exposed to an X-ray film.

Results and discussion. Cloning and screening of CP MLO DNA. Among 16 CP MLO-specific recombinant plasmids, 2 were selected for the construction of radioactively labelled DNA probes. One recombinant plasmid, named pCP16, contained CP MLO-specific DNA sequence of approximately $2.99 \mathrm{~kb}$ and the other, pCP110, contained a CP MLO-specific DNA fragment of approximately $5.96 \mathrm{~kb}$ (Fig. 1).

Specificity of $p C P 16$ and $p C P 110$ probes. In dot-blot hybridization, ${ }^{2} \mathrm{P}-$ labelled pCP16 and pCP110 hybridized with crude nucleic acids from CP MLO and PWB MLO-infected periwinkle plants but did not hybridize with crude 
nucleic acids from healthy, EAY MLO-, and AY27 MLO-infected periwinkle plants (Fig. 2). This result indicates that these probes are highly specific for the detection of CP MLO and PWB MLO. In Southern-blot hybridization, both undigested and digested DNA preparations from healthy, CP MLO-, and PWB MLO-infected plants were electrophoresed on agarose gels, transferred by capillary blotting onto Nylon Membrane and probed with ${ }^{22} \mathrm{P}$-labelled pCP16. The labelled probes hybridized only with chromosomal DNA associated with both CP MLO and PWB MLO. This result suggested that pCP16 contains some chromosomal DNA sequences associated with CP MLO and that it shares sequence homology with PWB MLO chromosomal DNA.

Detection sensitivity of $p C P 16$ and $p C P 110$ probes. The detection sensitivity of MLO by dot-blot hybridization using ${ }^{32} \mathrm{P}$-labelled pCP16 and pCP110 probes was estimated by establishing a minimum amount of plant midribs and petioles needed to reveal a positive hybridization signal. As soon as the periwinkle plants showed disease symptoms after graft transmission, midribs and petioles from young shoots and leaves were collected for preparation of crude nucleic acids. Two-fold serial dilutions of the nucleic acids were applied onto the membrane. Both CP MLO and PWB MLO were detected in a minimum of $30 \mu \mathrm{g}$ midribs and petioles (Fig. 2). Thus, recombinant plasmids pCP16 and pCP110 probes showed the same level of relatively high sensitivity. Our results that labelled pCP16 and pCP110 probes did not hybridize with DNAs from EAY and AY27 confirm that CP MLO is distinct from AY MLO isolates (Lee and Davis, 1988). Early reports also suggested that CP may be related to PWB (Chiykowski, 1965). Periwinkle plants infected by PWB MLO showed greening symptoms similar to those caused by CP MLO at the late stages of disease development. Therefore the possibility can not be excluded that CP MLO and PWB MLO are the same but that they are found in different hosts in Alberta under natural conditions. Upon accumulation of extensive sequence homology data for various MLO chromosomal or extrachromosomal DNAs, fairly detailed information will be available, leading to a better understanding of the genetic relationships of different MLOs.

Acknowledgements. This work was supported by an Operating Grant (A3843) from the Natural Sciences and Engineering Research Council of Canada to C. H. and a CIDA/University of Alberta Postgraduate Scholarship to S.D.

\section{References}

Ausubel, F. M. et al. (1987): Current Protocols in Molecular Biology. Wiley Interscience, New York, pp. 1.6.2.-1.6.4.

Chen, M. H., and Hiruki, C. (1975): Proc. Am. Phytopathol. Soc., 2, 52.

- (1978): Protoplasma, 95, 207-216.

Chiykowski, L. N. (1965): Can. J. Botany, 43, 527-536.

da Rocha, A., Ohki, S. T., and Hiruki, C. (1986) : Phytopathology, 76, 864-868.

Davis, M. J. et al. (1988) : Mol-Plant Microbe Interactions, 1, 295-302.

Hiruki, C. (ed.) (1988) : Tree Mycoplasmas and Mycoplasma Diseases. University of Alberta Press, Edmonton, p. 245.

Hiruki, C., and Chen, M. H. (1984) : Proc. 7th IUFRO Mycoplasma Conf., p. 7.

Kirkpatrick, B. C. et al. (1987): Science, 238, 197-200.

Lee, I.-M., and Davis, R. E. (1983): Phytopathology, 73, 1540-1543.

- (1988) : Mol. Plant-Microbe Interact., 1, 303-310.

Lin, C. P., and Chen, T. A. (1985) : Science, 227, 1233-1235. (1986): Phytopathology, 76, 45-50.

Maniatis, T., Fritch, E. F., and Sambrook, J. (1982) : Laboratory Manual, Cold Spring Harbor Laboratory, Cold Spring Harbor, New York, p. 327.

Sinha, R. C., and Chiykowski, L. N. (1984) : Can. J. Plant Pathol., 6, 200-205.

- (1986): ibid., 8, 387-393.

Southern, E. M. (1975) : J. Mol. Biol., 98, 503-517. 